\title{
Action Research of Holistic Conservation in Rawa Pening Fertilizer Engineering Technology and Lightweight Concrete By Academic-Business-Government-Community (ABGC) Synergy Approach
}

\section{Sri Mulyani Endang, Sugiyarta Stanislaus, and Fafurida}

Universitas Negeri Semarang

\section{Abstract}

Rawa Pening is the main reservoir in Semarang Regency which has experienced drastic silting. Approximately $70 \%$ of this 2.770 ha wide lake is now covered by eceng gondok (water hyacinth) plant. The quality of the lake gradually decreases

Corresponding Author: Sri Mulyani Endang alfinoorlaily@gmail.com

Received: 7 August 2018 Accepted: 15 September 2018 Published: 22 October 2018

Publishing services provided by Knowledge E

(c) Sri Mulyani Endang et al. This article is distributed under the terms of the Creative Commons

Attribution License, which permits unrestricted use and redistribution provided that the original author and source are credited.

Selection and Peer-review under the responsibility of the ICE-BEES 2018 Conference Committee. alongside its higher sedimentation. If this continues and not taken care of, it is predicted that in the following years, Rawa Pening will be a dry land if there is no prevention action being done. The objective of this action research, from the upstream is to perform an introduction of watershed conservation with vetiver plants to decrease the water rate and avalanche. On the other side, from the downstream, the objectives are: 1) retrieval of eceng gondok in a massive amount, 2) utilization of eceng gondok from the leaves to roots as materials to produce fertilizer, livestock food, and lightweight concrete, 3) collaboration with private sectors to produce fertilizer, livestock food, and lightweight concrete based on eceng gondok plant, 4) business unit establishment as the means of fertilizer, livestock food, and lightweight concrete marketing. The methodology being employed in this research is participative from stakeholders which consists of academics, government, business, and community, which is done comprehensively. Due to the effort of problem handling in Rawa Pening, the expectation is sedimentation problem to be solved, the community around the lake both sailors or farmers can utilize Rawa Pening again as one of their means of work, private sectors that produce eceng gondok-based product will get raw materials guaranteed-availability and create innovation of products based on eceng gondok, such as fertilizer, lightweight concrete and herbal products.

Keywords: Rawa Pening, eceng gondok, water hyacinth, fertilizer, lightweight concrete, stakeholder 


\section{Introduction}

Eceng gondok is a variety of water plant usually considered as fast-growing weeds that can strongly survive in its environment, thus can easily overflow within a brief period and cover water surfaces. Based on the research by Santiago (1973) in Syahputra (2005) done in Bogor, it showed that the increase number of its leaves, both damp and dry weight of the plant per day are approximately $7.5-12.5 \%, 13.8 \%$, and $17.4 \%$. This indicates the possible vast production of eceng gondok per day that may result in a drastic increase if an action is not being done. Eceng gondok, if not being taken care of, may grow up to 1 meter high while the approximate length in the water is $45 \mathrm{~cm}$. This may result in the water biota's needs of oxygen and sunlight to be unfulfilled since it is absorbed by eceng gondok covering the water surfaces [2].

Aside from the harm brought by the plant, eceng gondok has a respectable amount of natural fiber thus this plant is potential to be developed for natural fiber-based composites. One of the applications is to produce lightweight fibered-concretes. This is because the plant has a tenacious quality of fiber, a high content of fiber and is an abundant raw material, an affordable and easily obtained material, and a non-toxic plant. Eceng gondok consists of $90 \%$ water and has a $10 \mathrm{~kg}$ to $1 \mathrm{~kg}$ weight reduction level from wet to dry condition. In a dry condition, eceng gondok has a raw protein of $13.03 \%$, raw fiber of $20.6 \%$, grease of $1.1 \%$, and ash of $23.8 \%$, with the remaining of vortex consisting of polysaccharides and minerals.

To decrease the negative impacts of eceng gondok to the silting of water area, many efforts had been done to process it. This is not only to reduce the negative implications toward the environment but is also expected to give value-added to people's economy. The high lignin level in the plant enables the processing possibility of the plant to be a useful product and to have a high value for use; for example, the highly flexible fiber that can be developed as fertilizer. However, the utilization of eceng gondok is not comparable with its level of production which reaches $1.9 \%$ per day and its reproduction (10 eceng gondok plant can result to 600.000 within 8 months, Van Stenis in Bugir and Eka Pradana, 2011).

\section{Research Method}

The location of this research was Rawapening Lake, Semarang Regency, Central Java. The objective behind the location selection was because a sedimentation problem could be seen in Rawapening Lake due to the production of eceng gondok plant which 
needed immediate action to solve the problem. The method employed in the effort to solve the problem in Rawapening were as follow:

1. Experiment method and qualitative descriptive method which were used for trial and explanation about the process to create fertilizer, livestock food and lightweight concrete,

2. Partnership system between universities, industries, government, and community.

\section{Findings and Discussion}

Fertilizer is a material added to the soil to provide essential elements toward the growth of plants [3]. The action of maintaining the soil fertility and returning artificial nutrients are necessary so that the plant productions is normal or increasing. The aim in adding those artificial nutrients enables farmers to reach balance due to the missing nutrients from harvesting process, erosion, and other processes. The process of adding and returning nutrients to the soil is called fertilizing process. The variety of fertilizer used also needs to suit the needs, thus a correct diagnostic method needs to be employed to ensure that the nutrients added and returned to the ground are only limited to the necessities [4]. Concentration, time, and method of fertilizing need to be precise to prevent loss of profit and damage to the environment due to the overage amount of concentration, time and method of application.

Fertilizers can be categorized into two which are organic and non-organic fertilizer and its definition may differ based on its wide coverage. For example, if calculated based on the amount of nutrients, fertilizer is divided into single and compound fertilizer. Single fertilizer is used to supply one variety of nutrient, though there are other nutrients available as compound. On the other hand, compound fertilizer is a physical mix of combination or fertilizer formulation (two or more single fertilizer) to supply two or more nutrients all at once. Based on its method of application, artificial fertilizer can be differentiated into two which are leaves and root fertilizer. Leaves fertilizer can be given through spraying on the leaf parts of the plant, while root fertilizer can be absorbed by the roots through spreading it on the ground [5]. Moreover, organic fertilizer is the one in which most or all contents are formed by organic material from plants or animals through processing method. The form can be solid or liquid and used to supply organic material and repair physical nature, chemical, and biology of soil [8]. 


\section{The Mechanism of Roots and Leaves Fertilizer}

Root is a non-photosynthetic organ of the plant. The nutrients absorbing process from the root surface to the plants' core is a complex mechanism [4]. The absorbing process of ion to the plants' root occurs through 3 type of mechanisms which are ion exchange, diffusion, and carrier activity or ion-ligature metabolic compounds. Ion exchange mechanism is a passive mechanism. Suyatmo (2010) stated that nutrient absorbing process by this mechanism occurs due to the contact between the root surface and soil colloid. Diffusion method is an active transport mechanism of ion to the outer space/free space of the root located on the epidermis wall and cortex cell from the root and water film that covers the intercellular cavity. The diffusion process happens due to the different concentration between water surface and soil solution. The third mechanism is the carrier activity, in which an active transport occurs in the inner space. The nature of this transport is selective in ion absorbing thus from this mechanism, plants generally have the ability to select which nutrient is necessary and which is dangerous thus needed to be filtered from being absorbed by plants.

The mechanism of obtaining nutrients from the leaves occurs because of the diffusion and osmosis through stomata hole, thus the process is highly dependent to the opening and closing of the stomata. The opening of stomata is a mechanical process regulated by the turgor pressure through closing cells. The turgor pressure itself is directly reliant to the carbon dioxide content of the space under the stomata. The increase of turgor pressure will open the hole of stomata thus allowing nutrients to diffuse inside the stomata alongside water [7]. For example, the form of stomata in rice fields plant such as halter has a thick texture from the middle part of its closing cell wall, in which it functions as a cantilever in halter. Each corner of the wall has thin cells, while the upper part and the bottom of the wall has a thick texture [9]. Rice plants has a pin feather and Si-contented nutrient which is speculated to cause the difficulty of leaves fertilizer absorbing process. The location of stomata in plants generally is under the surface of the leaves.

\section{Conclusion}

The process of liquid organic fertilizer production is actually very easy and simple. The materials used are also abundantly available around us. The macro and micro nutrients inside the organic fertilizer from household production is also not inferior in quality from fertilizer sold on the market. Most importantly, we have to be able to 
choose a good quality of materials to produce liquid organic fertilizer according to the reference of mixture content that we have understood. By that, it is expected that the final product of homemade liquid organic fertilizer can bring a significant advantage on the fields.

The advantages and benefits of liquid organic fertilizer usage are as follow:

1. Fertilizing the soil,

2. Repairing the organic structure so that the soil is not rough and hard,

3. Maintaining the stability of nutrients availability in soil,

4. Reducing the negative impacts of rubbish on the environment,

5. Having an easy and simple production process of the fertilizer,

6. Having an affordable means of production due to the usage of residual materials around us,

7. Having no side effects to the users or the plants,

8. Having a healthier crop to be consumed and durable in storage.

The disadvantages of liquid organic fertilizer use are as follow:

1. Needs perseverance and high patience since the initial usage may not give a significant fertilizing effect to the plants compared to the use of chemical products, especially if applied to the chemical well-adapted soil for years.

2. Prone to erosion because it may be carried away by rain and overdosage of sprinkling.

The production of liquid fertilizer from eceng gondok can be done by Penta helix method by the academics as the idea originator of the fertilizer, business as the marketer, government as the policy maker to the use of fertilizer, and community as the producer and consumer of the fertilizer and banking as the fund supplier.

\section{References}

[1] Bagir, Achmad dan Eka Pradana, Gigih.2011.Pemanfaatan Serat Eceng Gondok sebagai Bahan Baku Pembuatan Komposit.[terhubung bekala]. http://eprints. undip.ac.id/36736/1/38. ECENG_GONDOK.pdf. (21 Oktober 2013). 
[2] Gerhard. 2013."Valuasi Ekonomi Sumber Daya alam Rawa Pening dan Strategi Pelestariannya di Kabupaten Semarang". Skripsi. Fakultas Ekonomika dan bisnis, Universitas Diponegoro

[3] Hadisuwito, S. 2008. Membuat Pupuk Kompos Cair. AgroMedia Pustaka. Jakarta. 56 hlm.

[4] Leiwakabessy, F. M. dan A. Sutandi. 2004. Pupuk dan Pemupukan. Diktat Kuliah. Departemen Tanah. Fakultas Pertanian. IPB, Bogor.

[5] Novizan.2001. Petunjuk Pemupukan yang Efektif. Agro Media Pustaka, Jakarta.

[6] Rorong Johnly A, Suryanto, Edi. 2010. Analisis fitokimia enceng gondok (Eichhornia crassipes) dan efeknya sebagai agen photoreduksi Fe3+. Chem. Prog. 3(1): 33-41.

[7] Setyamidjaja, Djoehana. 1986. Pupuk dan Pemupukan. Jakarta: CV. Simplex.

[8] Simanungkalit, R.D.M. 2006. "Pupuk Organik dan Pupuk Hayati (ORGANIC FELTILIZER AND BIOFERTILIZER". Balai Besar Litbang Sumberdaya Lahan Pertanian. Badan Penelitian dan Pengembangan Pertanian (BPPP).

[9] Sutrian, Yayan. 1992. Pengantar Anatomi Tumbuh-Tumbuhan edisi revisi. Jakarta. Rineka Cipta. Hal: 141.

[10] Syahputra, R. (2005). Fitoremediasi Logam Cu dan Zn dengan Tanaman Eceng Gondok (Eichornia crassipes (mart.) solms). Jurnal Logika 2(2): 57-66. ISSN: 14102315.

[11] Van Steenis, D. Den Hoed, S. Bloembergen \& P.J. Eyma. 1975. Flora untuk sekolah di Indonesia. Jakarta Pusat: PT Pradnya Paramita.

[12] www.green.web.id

[13] www.green.kompasiana.com

[14] www.kencanaonline.com 